\title{
Ensaio para uma revisão do sistema de recursos no Código de Processo Civil. (*)
}

\author{
Alfredo Buzaid \\ Docente de Direito Judiciário Civil na Faculdade \\ de Direito da Universidade de São Paulo.
}

\section{A elaboração do código de processo civil.}

1 - Pouco depois da outorga da Carta de 10 de novèmbro de 1937, procurou o Govêrno da República dotar o país de novos Códigos, pondo-os em harmonia com a estrutura constitucional então vigente. O Ministro da Justiça confiou ao eminente jurisconsulto Pedro Batrsta MarTiNs a elaboração do ante-projeto do Código de Processo Civil. A 4 de fevereiro de 1939, ou seja, cêrca de um ano após a inauguração daquele regime político, já o Diário Oficial da União publicava ante-projeto do Código, a fim de receber sugestões. A 24 de julho do mesmo ano era

(*) Conferência proferida pelo Prof. Alfredo Buzaid, no dia 10 de junho de 1955, na Faculdade de Direito de Pelotas, da Universidade do Rio Grande do Sul. Em resposta à saudação do Prof. Alcides de Mendonça Lima, disse as seguintes palavras iniciais: "Eu agradeço, muito sensibilizado, as palavras de tão carinhosa recepção, que bem traduzem os altos sentimentos do povo rio-grandense, e, especialmente, desta douta comunidade de Pelotas. Conheço, pela história e pela tradição, o que é o grande coração gaucho, e, de modo particular, o que representa êste pugilo de heróis que, no passado, continuando através do presente, vêm interferindo decisivamente no curso dos acontecimentos, criando ou modificando os destinos do Brasil. Aos mestres eminentes desta Casa deixo os meus cumprimentos cordiais e expresso o tributo de minha irrestrita admiração." 
submetido à aprovação do Presidente da República o projeto, que veio a converter-se em Código de Processo Civil, baixado como decreto lei $n .^{\circ} 1.608$. Neste último período intensa foi a atividade do ilustre autor do projeto, estudando, discutindo e criticando as sugestões enviadas por juristas, entidades de classe, Tribunais e Faculdades de Direito. No curto espaço de seis meses, apreciadas as emendas e brunido o texto, a obra estava totalmente concluída.

2 - Mas um Código, para conquistar foros de monumento legislativo de vida duradoura, deve ser escrito em linguagem escorreita, consagrar princípios unitários e compor o conjunto, distribuindo simètricamente tôda a matéria. $\mathrm{Na}$ redação das leis não basta, portanto, o emprêgo dos vocábulos com propriedade e elegância. É necessário que se guarde a unidade do plano e a coerência do sistema. Quando se elaborou o Código de Processo Civil, não teve a nação brasileira um contacto vivo com o legislador, através de discussões largas e públicas de todos os problemas que estavam sendo suscitados. Um dia, surge o Código, publicado pela imprensa oficial para entrar em -vigor pouco depois...

3 - No Código de Processo Civil podem distinguir-se quatro partes fundamentais: a) a primeira se ocupa do chamado processo de declaração (do art. $1 .^{\circ}$ ao art. 297); b) a segunda, a maior de tôdas, compreende numerosos processos especiais (do art. 298 ao art. 807); c) a terceira é dedicada aos recursos (do art. 808 ao art. 881); d) a quarta e última abrange o processo de execução (art. 882 ao art. 1.050). Tal é, num rápido bosquejo, a distribuição das matérias. A primeira parte, elaborou-a o legislador segundo os princípios mais modernos da ciência do processo, consagrando o sistema da oralidade, da concentração e da identidade da pessoa física do juiz. Serviram-lhe de modêlo os Códigos da Áustria, da Alemanha e de Portugal; nesses diplomas, bem como nos trabalhos preparatórios de revisão legislativa feitos na Itália, foi o legislador brasileiro 
buscar a soma de experiências e encontrar os altos horizontes, que a ciência pudera dilatar, a fim de construir tôda uma sistemàtica nova, de fecundos resultados práticos.

4 -- Mas o legislador brasileiro, que se empenha em elaborar com rigor científico a primeira parte, não é feliz nas demais. Mantém injustificàvelmente uma série exaustiva de ações especiais (do art. 298 ao art. 807), minuciosamente reguladas, e engloba, nesses quinhentos artigos, que compreendem quase a metade do Código, processos de jurisdição contenciosa e voluntária, dispostos sem ordem, sem unidade e sem sistemática. Vergando ao pêso da tradição, conserva as linhas fundamentais do quadro de recursos, que herdamos de Portugal, com as distinções sutís, que os tornam um instrumento de difícil manêjo. O processo de execução, que reproduz quase em tudo o Regulamento n. ${ }^{\circ}$ 737 , não contém senão algumas pequenas e tímidas inovações. Sente-se, ao tomar contacto com o Código, que há nêle duas almas: na primeira parte, uma alma viva e atualizada com o progresso contemporâneo da ciência; nas demais, uma alma envelhecida. Cada qual fala a sua própria linguagem. E por isso que se não casam harmônicamente.

5 - Dentre tôdas as partes do Código, aquela que apresenta maiores defeitos é, sem dúvida nenhuma, a do sistema geral de recursos. Múltiplo, complexo e eriçado de dificuldades, constitui uma fonte permanente de tropêços para os que lidam no fôro e uma arma poderosa de procrastinação dos feitos. Antes, porém, de se proceder à análise e crítica do direito positivo nacional, é de todo interêsse verificar como, nos nossos tempos, outros povos resolveram o problema da impugnação das sentenças não transitadas em julgado, lembrando-se especialmente os Códigos em que se inspirou a reforma processual brasileira. Um estudo de direito comparado nos dará uma idéia do sistema adotado pelos países civilizados e permitirá o cotêjo com o quadro de recursos mantido no Código de Processo Civil nacional. 


\section{Direito comparado.}

6 - Segundo a lição dos autores (1), o Código de Processo Civil alemão regula ùnicamente três recursos: a apeIação (die Berufung), a cassação (die Revision) e o agravo (2) ou queixa (die Beschwerde) (3). É admissível a apelação de sentenças definitivas proferidas em primeira instância ( $\S 511$ ); a cassação, de sentenças definitivas proferidas em gráu de apelação pelos Tribunais $(\$ 545, \mathrm{I})$; e o agravo, das demais decisões de menor importância, especialmente despachos (\$567). Assim, pois, atendendo à natureza do provimento jurisdicional, pode dizer-se que a apelação e a cassação são recursos destinados a impugnar sentenças definitivas (Endurteile), inclusive as de reserva (Vorbehaltsurteile: $\S \S 302$. III e 599, III) e ainda certas sentenças incidentes (Zwischenurteile: $\S \S 275$, II e 304, II), consideradas definitivas para efeito de recursos. O agravo é admissível, além dos casos expressos (4) no Código ( $\$ \S$

(1) ScHönke, Lehrbuch des Zivilprozessrechts, 7. ${ }^{\mathrm{a}}$ ed. p. 339; ROSENBERG, Lehrbuch des deutschen Zivilprozessrechts, $5 .^{a}$ ed. p. 606; de Boon, Zivilprozessrecht, p. 119; WACH, Vorträge über die Reichs - Civilprocessordnung, Bonn, 1896, p. 244; Nikisch, Zivilprozessrecht, Tübingen, 1952, p. 464.

(2) João Mendes Júnior (Direito Judiciário Brasileiro, 2. ${ }^{\mathrm{a}}$ ed. p. 484, nota) traduz a palavra Beschwerde por agravo.

(3) Além dos recursos pròpriamente ditos, conhece o direito alemão outros meios de impugnar decisões, que recebem o nome de remédios (Rechtsbehelfe), a saber: reposição da causa no estado anterior ( $\$ 233$ ); oposição contra sentença contumacial ( 3338 ); e a oposição contra o despacho de penhora (§ 924). A rescisória dos julgados (Wiederaufnahme des Verfahrens: § 578) é uma ação, não um recurso.

(4) ZPo § 46 (suspeição do juiz); § 102 (condenação em custas de funcionários, advogados, oficiais do juizo); § 104 (reposição na conta de custas); § 109 (devolução de fiança); § 127 (denegação ou revogação do benefício da justiça gratuita); $\$ 252$ (que concede ou denega a suspensão do processo); $\$ 319$ (correção de êrros materiais 
$46,102,104,109,127,252,319,336,380,390,699,793,934$ e 1.045), de todos os despachos que não exigem debate oral e em virtude dos quais se repele uma reclamação referenteao processo. A apelação e o agravo provocam um novo exame sôbre a matéria de fato e de direito, ao passo que a cassação se limita à questão de direito da sentença recorrida. Por via de regra, o recurso de cassação visa a anular a sentença e só excepcionalmente autoriza a entrar no exame do mérito (5). A apelação e o agravo objetivam, ao contrário, um novo julgamento, que substitui o primeiro; só excepcionalmente se devolverá a causa à primeira instância (6). Ficam, porém, submetidas ao Tribunal de Apelação as decisões que antecedem as sentenças definitivas, salvo as que são inapeláveis ou que possam ser impugnadas pelo agravo (unanfechtbar oder mit der Beschwerde anfechtbar sind) (7).

da sentença); $\S 336$ (denegação de sentença contumacial); $\S 380$ (condenação de testemunha que não comparece em juizo); $\S 390$ (condenação de testemunha que deixa de jurar, prestar declaração: ou é desobediente); § 699 (denegação do mandado de execução); $\S 793$ (decisão em matéria de execução forçada); § 934 (levantamento da penhora); $\$ 1.045$ (nomeação de árbitros).

(5) ZPO. § 565, I.

(6) ZPo. § 538: O Tribunal de Apelação devolver'á a causa ã primeira instância, desde que seja necessário novo tratamento: $1^{\circ}$ se pela sentença impugnada foi repelida por inadmissível a oposição do revel Einspruch: zPo. $\$ 342$ ); $2 .^{\circ}$ se pela sentença impugnada sòmente foi decidida uma exceção processual (nur über prozesshindernde Einreden); $3 .^{\circ}$ no caso de uma ação discutida em seu fundamento e em seu valor, se a sentença houver resolvido antecipadamente sôbre o primeiro ou rejeitar a ação, salvo se a questão sôbre a importância da demanda estiver suficientemente madura para sentença; $4 .^{\circ}$ se a sentença impugnada houver feito reserva de direito no processo documental e cambiário; $5 .^{\circ}$ se a sentença impugnada fôr contumacial (Versäumnisurteil).

(7) zPo. § 512; cf. RosenberG, Lehrbuch, p. 618; Stein-JonasScHöNke, Kommentar zur Zivilprozessordnung, 17. ad. obs. I ao $\S 512$. 
7 - No direito austríaco, o código denomina Rechtsmittel os seguintes meios de impugnar as decisões não transitadas em julgado: apelação, (die Berufung), a cassação (die Revision) e o recurso (Rekurs) (8). A apelação e a cassação visam à revogação ou à reforma ùnicamente de sentenças (Urteile), ao passo que o recurso (Rekurs) tem por objeto despachos (Beschlüsse) proferidos no curso da audiência e decretos judiciais (Bescheide) (9). O Tribunal conhece a decisão de primeira instância nos limites do pedido formulado pelo apelante, $\mathrm{e}$, ao mesmo tempo, também os despachos proferidos no processo antes da sentença, desde que a sua impugnação não tenha sido excluída pela lei, ou êles não se tornaram imutáveis em consequência da falta de reclamação tempestiva ou por fôrça de decisão proferida sôbre o recurso interposto (10). No sistema austríaco, a apelação só é admitida, pois, contra decisões que julgam uma questão prejudicial, ou a lide no todo ou em parte; dos despachos, proferidos no curso do processo e destinados a preparar a sentença final, não cabe, por via de regra, recurso distinto, sendo impugnados juntamente com a apelação de sentença definitiva. É o que se chama a apelação concentrada. O poder de o Tribunal apreciar tais despachos não depende da interposição de recurso especial, decorre do efeito devolutivo da apelação, segundo o qual pode a Superior Instância conhecer de ofício de tôdas as decisões que influiram na prolação da sentença apelada, salvo as restrições previstas no $\S 462$. Nas causas de pequeno valor (Bagatellsachen), a sentença de primeira

(8) cf. WoLfF, Grundriss des österreichischen Zivilprozessrechts, Wien, 1947, 2. ${ }^{a}$ ed. p. 345; NeUManN, Kommentar zu den Zivilprozessgesetzen, 2. ${ }^{a}$ ed. II, p. 1207; SchrutKa, Grundriss des Zivilprozessrechts, 2. ${ }^{a}$ ed. p. 265; KLEIN-ENGEL, Der Prozess Oesterreichs, 1927, p. 403.

(9) Cf. zPo, $\S \S 461,502$ e 514.

(10) ZPO, § 462; SchrutKA, op. cit. p. 267. 
instância só pode ser impugnada por apelação, que se funde em nulidade enumerada no $\S 477$ do zPo (11). Dos despachos e decrelos judiciais, se a lei não exclui a impugnação, cabe o recurso (Rekurs) (12). Nos casos em que, segundo as regras do Código, não é admissível contra despachos e decisões um recurso separado, podem as partes reclamar o gravame sofrido, por ocasião em que recorrem da decisão impugnável (13).

O recurso de cassação é admissível de sentença proferida pelo Tribunal de Apelação (14). Nas causas de pequeno valor, das decisões proferidas pelo Tribunal de Apelação não cabe nenhum recurso (15).

8 - Sob a denominação genérica de "impugnação das sentenças", reune o Código de Processo Civil italiano os seguintes recursos: a apelação, a cassação, a revogação e a oposição de terceiros (16). Além dêsses recursos, conhe-

(11) ZPO. § 501; WolfF, op. cit. p. 361; KLEIN-ENGEL, op. cit. p. 403.

(12) zPO. §514; WolfF, op. cit. p. 366; KLEIN-ENGEL, op. cit. p. 451.

(13) zPo. § 5i15; NeumanN, op. cit. II, p. 1328.

(14) zPo. $\S 502$. Cabe o recurso de cassação: I — quando a :sentença do Tribunal de Apelação é nula por um dos vícios indicados no § 477; II — quando o procedimento da apelação está contaminado por um defeito que, sem produzir a nulidade, era tal que impedia, um tratamento completo e um julgamento de mérito da causa; III - quando, na base da sentença do Tribunal de Apelação, em um ponto essencial, foi estabelecido um pressuposto de fato que está em contradição com atos processuais de primeira a segunda instância; IV - quando a sentença do Tribunal de Apelação se apóia sôbre um julgamento da causa errado segundo o direito.

(15) ZPO. § 502.

(16) Codice di Procedura Civile, art. 323. Veja-se para o direito italiano, Liebman, Corso di Diritto Processuale Civile, Milano, 1952, p. 203 e segs,; Redenti, Diritto Processuale Civile, Milano, 1953, vol. II, p. 407 e segs; UGo Rocco, Corso di teoria e pratica deb processo civile, vol. II, p. 171 e segs.; CARNELUTTI, Istituzioni del 
ce o direito italiano o chamado "regolamento di competenza" cujo objetivo é o de provocar diretamente da Côrte de Cassação uma decisão separada sôbre a questão de competência surgida na causa, com eficácia definitiva e vinculativa para todos os juízes (17). A apelação é o recurso ordinário e normal, admissivel de tôdas as sentenças proferidas em primeira instância, desde que não esteja excluída pela lei ou por acôrdo das partes (18). São, porém, inapeláveis as sentenças proferidas segundo a equidade e as do conciliador, nas causas de valor inferior a duas mil liras (19). Antes das modificações introduzidas pela lei n. ${ }^{\circ} 581$ de 14 de julho de 1950, as decisões parciais e interlocutórias (20) eram impugnáveis sòmente em conjunto com a apelação da sentença definitiva, mas o exercício dêsse direito estava condicionado à manifestação de reserva, que no texto originário do Código prescrevia: "la parte che intende conservare il diritto di appellare contro una sentenza parziale deve farne espressa riserva, a pena di decadenza, nella prima udienza sucessiva alla communicazione della sentenza, salvo il disposto dell'articolo 284." (21). Essa disposição suscitou vivas críticas e animadas

nuovo processo civile, $4 .^{\mathrm{a}}$ ed. vol. II, p. 127 e seg.; ZANZUCCHI, $D i$ ritto Processuale civile, $4 .^{\text {a }}$ ed. vol. II, p. 149 e segs.; Sergio Costa, Manuale di Diritto Processuale Civile, p. 366 e segs.; JAEger, Diritto Processuale Civile, Torino, 1944, p. 486 e segs.; Andrioli, Commento al Codice di Procedura Civile, II, p. 273 e segs.; PAolo d'Onofrio, Commento al Codice di Procedura Civile, $2 .^{\mathrm{a}}$ ed. v. I, p. 411 e segs.

(17) Cfr. Liebman, Manuale di diritto Processuale Civile, Milano, 1955, I, p. 125.

(18) Cod. Proc. Civ. art. 339.

(19) Cod. Proc. Civ. art. 339, II.

(20) Liebman, Corso cit. p. 213: "Per le sentenze non definitive (parziali e interlocutorie) l'appello, anziche proporsi immediatamente, può essere differito, purché la parte interessata ne faccia riserva, a pena di decadenza. "

(21) Cod. Proc. Civ. art. 340. 
controvérsias (22), dando lugar à reforma legislativa, que consagrou princípio diverso. $\mathrm{O}$ texto vigente do art. 340 está assim redigido: "Riverva facoltativa di appello contro sentenze non definitive. Contro le sentenze previste dall'art. 278 e dal n. 4 del secondo comma dell'art. 279, l'appello può essere differito, qualora la parte soccombente ne faccia riserva, a pena di decadenza, entro il termine per appellare e, in ogni caso, non oltre la prima udienza al giudice istruttore successiva alla comunicazione della sentenza stessa.

Quando sia stata fatta la riserva di cui al precedente comma, l'appello deve essere proposto unitamente a quello contro la sentenza che definisce il giudizio o con quello che venga proposto, dalla stessa o da altra parte, contro altra sentenza successiva che non definisce il giudizio.

La riserva non può più farsi, e se già fatta rimane priva di effetto, quando contro la stessa sentenza da alcuna delle altre parti sia proposto immediatamente appello."

Por aí se vê que a apelação das decisões não definitivas, ou tem lugar em conjunto com apelação da sentença definitiva, mediante prévia reserva, ou pode ser interposta imediatamente, o que opera uma cisão na unidade do processo, permitindo que êle seja apreciado contemporâneamente em duas instâncias (23). Fracciona-se o processo em procedimentos que caminham simultâneamente (24).

As sentenças proferidas em grau de apelação, ou em instância única, excluídas as do conciliador, podem ser impugnadas mediante recurso de cassação: 1 - por motivos atinentes à jurisdição; 2 - por violação das normas sôbre competência, quando não está previsto o regulamento de competência; 3 - por violação ou falsa aplicação das normas de direito; 4 - por nulidade da sentença ou do pro-

(22) PaOlo d'ONofrio, Commento, cit. I, p. 437;

(23) Chrovenda, Instituições, III, n. 390.

(24) Liebman, Corso, p. 213. 
cesso; 5 - e por omissão, insuficiência ou fundamentação contraditória sôbre um ponto decisivo da controvérsia, suscitado pelas partes ou considerado de ofício (25). O recurso de cassação, como observou Liebman (26), "não dá lugar a uma terceira instância e a côrte de cassação não é chamada a decidir novamente a controvérsia, que normalmente já deve ter tido um duplo exame por parte do juiz de mérito. O recurso serve para denunciar ao órgão supremo da autoridade judiciária as sentenças que apresentam determinados vícios, taxativamente indicados pela lei." A função da Côrte de cassação é de assegurar a exata observância e uniforme interpretação da lei, a unidade do direito objetivo nacional, o respeito aos limites das diversas jurisdições, regulando os conflitos (27).

Para interpôr o recurso de cassação, o vencido precisa efetuar o depósito de uma importância a título de multa, se não houver provimento (28).

9 - O Código de Processo Civil português, um dos mais recentes publicados na Europa (29), classificou os recursos em dois grupos: a) ordinários; b) extraordinários. Os recursos ordinários são a apelação, a revista, o agravo, a queixa e o recurso para o tribunal pleno. Os recursos

(25) Cod. Proc. Civ. It. art. 360. Pode também ser Impugnada, mediante recurso de cassação, uma sentença apelável, se as partes estão de acôrdo em omitir a apelação; mas em tal caso o recurso só pode ter por fundamento violação ou falsa aplicação de normas de direito.

(26) Liebman, Corso, p. 220.

(27) R.D. 30 de Janeiro de 1941, art. 65, n. ${ }^{\circ} 12$; ainda cf. Sergio Costa, Manuale di Diritto Processuale Civile, 1955, p. 405.

(28) Cod. Proc. Civ. It. art. 364.

(29) O Código de Processo Civil de Portugal foi promalgado pelo Decreto-lei n. 29.637 de 28 de maio de 1939 . Sôbre o histórico de sua elaboração, ver: BARBoSA DE MAGALHÃEs, Estudos sôbre o novo Código de Processo Civil, p. 179. 
extraordinários são a oposição de terceiro e a revisão (30). $O$ recurso pode ser independente ou subordinado. Se ambas as partes ficarem vencidas, cada uma delas terá de recorrer se quizer obter a reforma da decisão na parte que lhe fôr desfavorável. Mas pode interpor um recurso independente ou um recurso subordinado. $O$ recurso independente há de ser interposto dentro do prazo e nos têrmos normais. $O$ recurso subordinado pode ser interposto dentro de cinco dias a contar da notificação do despacho que admite o recurso da parte contrária. Se o primeiro recorrente desistir do recurso ou êste ficar sem efeito ou o Tribunal não tomar conhecimento dêle, caduca o recurso subordinado, sendo tôdas as custas da responsabilidade do recorrente principal (31).

10 - Da decisão que admite o recurso não pode a parte contrária recorrer. Mas contra a que o não adinite pode o recorrente usar da queixa ao presidente do tribunal superior, que seria competente para conhecer do recurso (32). Cabe apelação: a) da sentença final e do despacho saneador, quando conhecer do mérito da causa; b) da sentença final proferida no incidente de falsidade e no de habilitação e da que julgar os embargos opostos ao arresto, ao arrolamento e ao embargo de obra nova, quando conhecer do objeto do incidente ou da oposição (33). O recurso de revista é admissivel: a) da sentença do tribunal de comarca proferida sôbre recurso de apelação quando conhecer do objeto do recurso e se verificarem os casos da segunda parte do art. $678(34) ;$ b) — do acórdão

(30) Cod. Proc. Civ. Port. art. 677.

(31) Cod. Proc. Civ. port. art. 682.

(32) Cod. Proc. Civ. Port. art. 689.

(33) Cod. Proc. Civ. port. art. 691.

(34) Cod. Proc. Civ. port. art. 678: "Só admitem recurso ordinário as decisões proferidas em causa de valor superior à alçada do tribunal de que se recorre. Mas se o recurso tiver por fundamento a incompetência absoluta do tribunal ou a ofensa do caso julgado, é sempre admissível seja qual for o valor da causa." 
da Relação proferido sôbre recurso de apelação, quando conhecer do objeto do recurso (35). O fundamento da revista é a violação da lei substantiva por êrro de interpretação ou de aplicação. Por lei substantiva devem entender-se: as regras de direito, de caráter substantivo, emanadas dos órgãos da soberania, nacionais ou estrangeiros; os usos e costumes quando tenham fôrça de lei; as convenções e os tratados internacionais (36). Podem ser alegadas accesóriamente as nulidades previstas nos artigos. 668 e 717 , depois de ter sido proferida sentença ou acórdão sôbre a argüição (37).

11 - Denomina-se agravo outra modalidade de recurso, admissível de decisões, susceptíveis de recurso, mas de que não se pode apelar (38). Sobe imediatamente o agravo interposto: $10^{\circ}$ do despacho que indeferiu in limine a petição inicial; $2 .^{\circ}$ do despacho saneador que puser têrmo ao processo; $3 .^{\circ}$ da decisão proferida sôbre as reclamações deduzidas contra o questionário. Os agravos interpostos de despachos proferidos depois da decisão das reclamações, contra o questionário só subirão com o recurso interposto da sentença final; $4 .^{\circ}$ do despacho pelo qual o juiz se declare impedido ou indefira o impedimento oposto por alguma das partes; $5 .^{\circ}$ da decisão proferida sôbre conflito

(35) Cod. Proc. Civ. port art. 721.

(36) Cod. Proc. Civ. port. art. 722 e $\S 1 .^{\circ}$.

(37) Cod. Proc. Civ. port. art. 668: "E nula a sentença: 1.o quando omitir os nomes das partes e a assinatura do juiz; $2 .^{\circ}$ quando não especificar os fundamentos de fato e de direito que justificam a decisão; $3 .^{\circ}$ quando os fundamentos estiverem em oposição com a decisão; $40^{\circ}$ quando o juiz deixar de pronunciar-se sôbre questões que devesse apreciar ou conhecer de questões de: que não podia tomar conhecimento; $5 .^{\circ}$ quando condenar em quantidade superior ou em objeto diverso do pedido." $\mathrm{Na}$ forma do disposto no art. 717 , é nulo o acórdão quando se verificar algum dos casos previstos no art. 668, acima transcrito.

(38) Cod. Proc. Civ. port. art. 733. 
de jurisdição ou competência; $6 .^{\circ}$ do despacho que anule todo o processo ou julgue incompetente o tribunal (39). O agravo ou sobe nos próprios autos, ou em separado. A regra adotada pelo Código português é que sobe nos próprios autos quando o processo termina, ou em separado quando o processo continua (40).

Cabe recurso de agravo para o Supremo Tribunal: $1 .^{\circ}$ da decisão do Tribunal de comarca, no caso previsto na última parte do art. $796 ; 2 .^{\circ}$ do acórdão da Relação que admita recurso, salvo nos casos em que couber recurso de revista ou de apelação (41). Êste agravo pode ter por fundamento: $1 .^{\circ}$ as nulidades indicadas nos arts. 668 e $717 ; 2 .^{\circ}$ a incompetência absoluta do tribunal ou a ofensa do caso julgado; $3 .^{\circ}$ a violação ou a errada aplicação da lei substantiva ou da lei de processo (42). A nulidade de sentença ou acórdão e a de processo só podem ser invocadas como fundamento de recurso depois de terem sido argüidas e em recurso interposto do acórdão proferido sôbre a argüição (43).

12 - Preocupação dominante na doutrina portuguêsa tradicional e moderna é a de uniformizar a jurisprudência (44). Realiza essa importante tarefa o Supremo Tribunal

(39) Cod. Proc. Civ. port. art. 734 e 735.

(40) José Alberto dos Reis, Código de Processo Civil, anotado, Coimbra, 1940, p. 511.

(41) Cod. Proc. Civ. port. art. 754.

(42) Cod. Proc. Civ. port. art. 755.

(43) Cod. Proc. Civ. port. art. 755.

(44) "Chamavão façanha", escreve Manuel de Almeida e Souza, “ao Juizo ou Assento, que se tomava sobre algum feito notável e duvidoso, que por autoridade de quem o fez e dos que o aprovarão, ficou servindo como de Aresto para se imitar e seguir como lei, quando outra vez acontecesse." (Segundas Linhas sobre o Processo Civil, Lisbôa, 1910, vol. I, p. 7). NAzARETH também assinalou que competia à Casa de Suplicação "interpretar autênticamente as leis por meio de assentos. Ord. lib. I, tit. $5, \S 5$ e Lei de 18 de agôsto de 1769, §§ 2 e 8" (Elementos do Processo Civil, Coimbra, 1860, 
de Justiça. Mas ò conflito de jurisprudência pode surgir no seio do mais alto órgão judiciário, adotando soluções opostas da mesma questão de direito. Ocorrendo a divergência, o vencido pode recorrer para o tribunal pleno do acórdão proferido em último lugar. Os acórdãos opostos hão de ser proferidos em processos diferentes ou em incidentes diferentes do mesmo processo. Neste último caso, se o primeiro acórdão constituir caso julgado para as partes, o recurso não é admissível. Como fundamento do recurso só pode invocar-se acórdão anterior com transitado em julgado (45). Decidindo-se que não existe oposição, - recurso considerar-se-á findo. No caso contrário, cada uma das partes terá dez dias para examinar o processo e apresentar a sua alegação sôbre o objeto do recurso; em seguida terá vista, por igual prazo o Ministério Público, que exporá sempre o seu parecer sôbre a solução a dar ao conflito de jurisprudência (46). A doutrina assente pelo acórdão que resolver o conflito de jurisprudência será obrigatória para todos os tribunais, enquanto não fôr alterada por outro acórdão (47).

13 - A revisão de qualquer sentença passada em julgado só pode ser requerida por algum dos seguintes fundamentos: $10^{\circ}$ quando se mostrar, por sentença condenatória passada em julgado em processo criminal, que foi proferida por peita, subôrno, corrupção ou prevaricação a sentença que se pretende fazer rever: $2 .^{\circ}$ quando se alegar a falsidade dalgum documento ou ato judicial, em que a sentença se fundasse, não se tendo discutido essa matéria no pro-

vol. I, p. 82). Cf. ainda: José Anastácio Figueiredo, sôbre qual seja o verdadeiro sentido da palavra Façanhas (Memórias de Literatura, vol. I, p. 61 e segs); JoÄo MENDES JúnIor, As formas da Praxe Forense, in Rev. da Faculdade de Direito, vol. XII, p. 9 segs.

(45) Cod. Proc. Civ. port. art. 763.

(46) Cod. Proc. Civ. port. art. 767.

(47) Cod. Proc. Civ. port. art. 768. 
cesso em que foi proferida a mesmı sentença; ou quando se apresentar sentença passada em julgado que tenha verificado a falsidade de depoimentos ou declarações de peritos que possam ter determinado a decisão a rever; 3. quando se apresentar documento novo de que a parte não dispuzesse nem tivesse conhecimento que, por si só, seja suficiente para destruir a prova em que a sentença se fumdou; $4 .^{\circ}$ quando se tiver revogado, ou houver fundamento para revogar, a confissão, desistência transação em que se fundasse a sentença; $5 .^{\circ}$ quando fôr nula, por irregularidade de mandato ou insuficiência de poderes do mandatário, a confissão, desistência ou transação, a que se referen os artigos 298 e seguintes, salvo se a sentença de homologação tiver sido notificada pessoalmente ao mandante; 6 quando, tendo corrido à revelia a ação e a execução, se mostrou que faltou ou foi nulamente feita a citação do rém; $7 .^{\circ}$ quando a sentença fôr contrária a outra que constizus caso julgado para as partes, formado anteriormente, se vencido mostrar que não teve conhecimento dêle enquanto o processo esteve pendente (48).

O direito português adotou também a oposição de terceiro. Quando as partes se tenham servido do processo para praticar um ato simulado e o tribunal não tenha feito uso do poder (49) que lhe confere o art. 665 por se nã ter apercebido da fraude, pode a sentença ser impugnada mediante o recurso da oposição de terceiro se tiver sido proferida em prejuizo do recorrente. O recurso não pode ser interposto enquanto a sentença não tiver transitado eme julgado ẹ o processo não baixar à primeira instância (50).

(48) Cod. Proc. Civ. port. art. 771.

(49) Cod. Proc. Civ. port. art. 665: "Quando a conduta das partes e quaisquer circunstâncias da cousa produzirem a convicção segura de que o autor e o réu se serviram do processo para praticar um ato simulado ou para conseguir um fim proibido por lei, a decisão deve obstar a êsse objetivo anormal."

(50) Cod. Proc. Civ. port. art. 778. 
O prazo para a interposição é de trinta dias contados da data em que o processo baixou ou da data em que o recorrente teve conhecimento da sentença (51). Tal é o sistema de impugnação das sentenças no direito português.

\section{Direito Positi̧vo Nacional.}

14 - Tudo isso viu o legislador brasileiro nos Códigos de Processo, que lhe serviram de modêlo. E que construiu? Ao invés de elaborar um sistema simples, coerente, lógico e em harmonia com os princípios da oralidade, concentração e identidade da pessôa física do juiz, - manteve, com ligeiros retoques, o quadro geral de recursos, que herdamos de Portugal. O Código vigente admite os seguintes recursos: I - apelação; II — embargos de nulidade ou infringentes do julgado; III - agravos (de petição, de instrumento e no auto do processo); IV - revista; V embargos de declaração; VI — e recurso extraordinário (52). Das sentenças de primeira instância, proferidas em ações de valor igual ou inferior a dois mil cruzeiros, só cabem embargos de nulidade ou infringentes do julgado e embargos de děclaração (53). Êstes são os recursos admissíveis nos chamados processos de alçada. Relativamente às ações de valor superior a dois mil cruzeiros, o Código admite quatro recursos, destinados a impugnar as decisões de primeira instância e devolver à instância superior o seu julgamento: a apelação e três agravos. Das sentenças definitivas de primeira instância, isto é, das decisões que julgam o mérito da causa, cabe, de ordinário, apelação (54). Das decisões que põem têrmo ao processo principal sem

(51) Cod. Proc. Civ. port. art. 779.

(52) Cod de Proc. Civ. nacional, art. 808.

(53) Cod. de Proc. Civ. art. 839.

(54) Cod. de Proc. Civ. art. 820. 
resolver o mérito, o recurso é de agravo de petição (55). Cabe agravo no auto do processo das decisões: I - que julgarem improcedentes as exceções de litispendência e coisa julgada; II - que não admitirem a prova requerida, ou cercearem de qualquer forma, a defesa do interessado; III — que concederem, na pendência da lide, medidas preventivas; IV - que considerarem saneado o processo (56). O agravo de instrumento é admissível de decisões taxativamente enumeradas no Código de Processo Civil (57). O legislador se fundou em um critério puramente casuístico, ao indicar as dezessete decisões sujeitas ao agravo de instrumento. O Código de Processo classificou, pois, quatro recursos contra decisões de primeira instância e definiu os requisitos de sua admissibilidade, atendendo à natureza do provimento jurisdicional. Dois dêles - a apelação e o agravo de petição - foram enunciados em fórmula genérica e pressupõem decisões finais, cabendo um ou outro conforme se decidiu ou não o mérito (58). Os agravos de instrumento e no auto do processo não suspendem o curso do processo, salvo as exceções previstas no art. 843; forma-se o primeiro, em autos distintos, por traslado de peças; o segundo é inserto no mesmo processo, mas só conhecido pelo tribunal por ocasião do julgamento da apelação interposta da sentença definitiva.

15 - Mas não é só. Na instância superior da justiça local podem ainda ser interpostos dois recursos: o de embargos de nulidade $e$ infringentes do julgado, quando não unânime o acórdão que, em grau de apelação, houver reformado a sentença (59); e o de revista, nos casos em que

(55) Cod. de Proc. Civ. art. 846.

(56) Cod. Proc. Civ. art. 851.

(57) Cod. Proc. Civ. art. 842.

(58) Liebman, in Instituições de Direito Processual Civil de Chiovenda, vol. III, p. 295.

(59) Cod. Proc. Civ. art. 833: “Além dos casos em que os permitem os arts. $783 \S 2$, e 839 , admitir-se-ão embargos de nulidade e infringentes do julgado, quando não fôr unânime a decisão 
divergirem, em suas decisões finais, duas ou mais câmaras, turmas, ou grupo de câmaras entre si, quanto ao modo de interpretar o direito em tese (60). Função análoga à revista tem o instituto do prejulgado; o Código de Processo Civil preceitua, no art. 861, que "a requerimento de qualquer dos seus juízes, a câmara ou turma julgadora poderá promover o pronunciamento prévio das câmaras reunidas sôbre a interpretação de qualquer norma jurídica, se reconhecer que sôbre ela ocorre, ou poderá ocorrer, divergência de interpretaçăo entre câmaras ou turmas". Ambos visam, portanto, a um fim comum: a uniformização da jurisprudência (61). Mas distinguem-se entre si, do ponto de vista subjetivo, porque a revista só pode ser requerida pela parte vencida, ao passo que o prejulgado é suscitado por qualquer dos juízes da câmara ou turma julgadora; do ponto de vista objetivo, a revista pressupõe divergência atual, ao passo que o prejulgado pode surgir mercê de eventual divergência futura.

16 - Mas não é tudo. A constituição permite o acesso ao Supremo Tribunal Federal, que é o órgão mais alto do Poder Judiciário, mediante dois recursos: um "ordinário" e outro "extraordinário". Ao Supremo compete julgar, em recurso ordinário: a) — os mandados de segurança, decididos em última instância pelos tribunais locais ou federais, quando denegatória a decisão; b) - as causas decididas por juízes locais, fundadas em tratado ou contrato da União com Estado estrangeiro, assim como as em que forem par-

proferida em grau de apelação, em ação rescisória e em mandado de segurança. Se o desacôrdo fôr parcial, os embargos serão restritos à matéria objeto de divergência" A nosso ver, êsse dispositivo legal, no que respeita ao mandado de segurança, foi parcialmente revogado pela lei $n .^{\circ} 1533$ de 31-XII-51, art. 20. Assim os acórdãos proferidos em recurso de mandado de segurança, na justiça local, não são mais embargáveis.

(60) Cod. Proc. Civ. art. 853 (redação da lei n. 1661, art. 1).

(61) cf. Mário Guimarães, Recurso de Revista, p. 19 e 107. 
tes um Estado estrangeiro e pessoa domiciliada no pais (62); e, em recurso extraordinário, as causas decididas em única ou última instância por outros tribunais ou juizes: a) - quando a decisão fôr contrária a dispositivo da Constituição ou à letra de tratado ou lei federal; b) - quando se questionar sôbre a validade de lei federal em face da Constituição e a decisão recorrida negar aplicação à lei impugnada; c) - quando se contestar a validade de lei ou ato de govêrno local em face de Constituição ou de lei federal e à decisão recorrida julgar válida a lei ou o ato; d) - e quando na decisão recorrida a interpretação da lei federal invocada fôr diversa da que lhe haja dado qualquer dos outros tribunais ou o próprio Supremo Tribunal Federal (63).

O Supremo Tribunal Federal está dividido em duas turmas. Compete à turma julgar recurso extraordinário (64) e ao Tribunal Pleno, recurso ordinário (65). Admitem-se ainda embargos de nulidade ou infringentes às decisões terminativas do feito proferidas: I - pelo Tribunal Pleno: a) nas ações cíveis originárias; b) nas recisórias dos seus julgados ou das Turmas; c) e nas homologações das sentenças estrangeiras; II _- pelas Turmas: a) nas apelações, quando houver sido reformada por simples maioria, a sentença de primeira instância (Cód. Proc. Civ. art. 833); b) nos recursos extraordinários, quando o acórdão, tomando conhecimento do recurso, houver decidido a questão federal que o motivou; c) nos executivos fiscais - nos casos

(62) Constituição Federal, art. 101, II.

(63) Constituição Federal, art. 101, III.

(64) Cf. Regimento Interno do Supremo Tribunal Federal, art. $1 .^{\circ} \S 2 .^{\circ}$; art. 24 , I.

(65) Cf. Regimento Interno cit. art. 23, II e III. Todavia, compete à turma julgar os recursos ordinários das decisões dos juízes locais nas causas em que a União ou Autarquia, que desempenhe serviço federal, fôr interessada, como autora, ré, assistente ou opoente (Reg. Int. 22, II, "c"). 
previstos no art. 73 do decreto-lei $n .^{\circ} 960$ de 17 de dezembro ale $1938(66)$.

E, por último, cindido o Supremo Tribunal em turmas, poderia surgir dissídio jurisprudencial entre elas, pondo em risco a unidade do direito nacional; a fim de obviar a êsse manifesto inconveniente, a lei n. ${ }^{\circ} 623$ mandou acrescentar 20 art. 833 o seguinte $\S$ único: "além de outros casos admikidos em lei, são embargáveis, no Supremo Tribunal Federal, as decisões das Turmas, quando divirjam entre si ou de decisão tomada pelo Tribunal Pleno." (art. 1. ${ }^{\circ}$ ). Tisse recurso, denominado embargos, representa, no Supremo Tribunal Federal, função análoga à revista na esfera da justiça local; tende uniformizar a jurisprudência, gravemente comprometida pela criação de turmas no seio da mais alta Côrte.

Tal é, num bosquejo realista, o sistema de recursos no Cỏdigo de Processo nacional.

\section{O princípio do duplo grau.}

17 - Uma aspiração comum de todos os povos, em codos os tempos, foi a de realizar a justiça, tanto quanto possível perfeita, nas decisões judiciais. Èsse ideal pode ser conseguido no tratamento das causas em uma única instância. Mas a natural contingência da falibilidade humana levou os legisladores a instituirem um sistema de contrôle e reexame da sentença por um tribunal superior, denominado segunda instância, para o qual devem recorrer as partes vencidas e inconformadas com a sentença proferida em primeiro grau (67). Essa renovação do processo ou reiteração da inștância dá lugar à criação de um sistema de tribunais distintos, autônomos e hieràrquicamente jus-

(66) Cf. Regimento Interno cit. art. 194.

(67) Liebman, Corso di Diritto Pročessuale Civile, Milão, 1952, p. 201. 
tapostos e de um sistema de recursos, que opera a devolução da matéria decidida aos orgãos superiores. O recurso é, portanto, o meio instituído pela lei para permitir o acesso à segunda instância das ações julgadas em primeira (68).

Esse ideal de submeter as sentenças a um novo exame por orgãos judiciários hieràrquicamente superiores foi realizado de modo diverso nos povos civilizados e nas várias épocas. A primeira consideração gira em tôrno do número de reexames, uma vez que não é possível estabelecer uma verificação indefinida. Como a justiça tardia pode ser também uma injustiça (69), procurou-se um ponto de equilíbrio entre o desejo de melhorar a decisão per gradus e a necessidade de concluir o processo sem delongas. "O sistema da lei", escreveu Redenti, "constitui a composição (ponto de equilíbrio) de duas exigências ou tendências antitéticas: a de consentir o controle $e$ o aperfeiçoamento per gradus das decisões judiciais e a de garantir em um certo momento a certeza final." (70)

Não é pelo número de reexames que se mede o grau de justiça de uma sentença. Já nas fontes romanas se assinala quão frequente é o uso da apelação, porque certamente corrige a injustiça e a imperícia dos julgadores, mas também se reconhece que não raro a instância superior

(68) Os recursos são remédios processuais, destinados a submeter uma decisão judicial a um novo exame na instância superior, impedindo assim a formação da coisa julgada. Suspender a formação da coisa julgada (efeito suspensivo) e determinar a competência do Tribunal Superior (efeito devolutivo), - tais são as características do recurso (ScHONkE, Lehrbuch des Zivilprozessrechts, 7. ${ }^{\mathrm{a}}$ ed. p. 339; GOLDSCHMIDT, Zivilprozessrecht, § 64, 1).

(69) Bacon, Tratado de Moral e Política, p. 53: "Se a injustiça da sentença a torna amarga; as delongas fazem=na azeda."

(70) Redenti, Diritto Processuale Civile, Milão, ed. Giufrré, 1953, 2. ${ }^{\text {a }}$ ed. vol. II, p. 308. 
reforma para pior as sentenças bem proferidas, pois não julga melhor quem julga por último:

Dig. 49.1.1: (Ulpiano libro I de Appellationibus) : Appellandi usus quam sit frequens, quanque necessarius, nemo est qui nesciat; quippe quum iniquitatem iudicantium, vel impericiam recorrigat, licet nonumquen bene latas sententias in peius reformet; neque enim utique melius pronuntiat, qui novissimus sententiam laturus est.

E certo que os tribunais de segunda instância também erram. Mas não é menos verdade que êles reunem maior tirocínio e experiência, além de ilustração e cultura, adquiridas ao longo dos anos no exercício da função judiciária (71).

18. - Quando o legislador brasileiro adotou, no Código de 1939, o chamado processo oral e concentrado, deparou desde logo com um grave problema: o da variedade de recursos. $\mathrm{O}$ antigo processo civil brasileiro, inspirado no sistema canônico-romano, era essencialmente escrito. Porém, na esfera dos recursos, se separou do modêlo europeu e construiu um sistema original, que representa o sincretismo de dois princípios: o romano e o germânico. Segundo o primeiro, só era apelável a sentença de mérito (sententia), em contraposição à interlocutio, que, servindo para decidir questões relativas ao expediente da demanda, ou à produção das provas, não era impugnável, ou antes, não era apelável (72). Em tudo diverso era o princípio germânico. "O princípio de direito germânico em virtude do qual tôda resolução de questões no curso do processo era considerado como sentença (interlocutória) e sobretudo se resolvia por sentença (probatória) a questão concernen-

(71) João Monteino, Processo Civil, § 199.

(72) Alfredo Buzaid, Do Agravo de Petição, n. 3. 
te à prova (onus de prova e gênero de prova) e tôda sentença definitiva ou interlocutória era sujeita a recurso, prevalaceu no direito medieval italiano sôbre o princípio romano, que considerava como sentença apenas a sentença de acolhimento ou de rejeição e não admitia recursos autônomos das interlocutórias" (73). Passou êste princípio para o antigo direito português, que conservou a apelação como recurso admissível de sentença definitiva e concedeu agravos de decisões interlocutórias com fôrça de definitiva ou que causassem dano irreparável. Os agravos foram classificaḍos em três espécies: de petição, de instrumento e no auto do processo (74). Mantida essa nomenclatura através dos séculos, não era certamente fácil ao legislador de 1939 romper um sistema de recursos, que carregava o pêso e a autoridade de uma longa tradição (75).

19. - O direito brasileiro se ressente, entre outros, de dois defeitos fundamentais: a) do ponto de vista terminológico, o emprêgo de uma expressão única para designar

(73) ChIovenda, Instituições, cit. vol. III, p. 318

(74) Alfredo BuzaId, Del agravio en el auto del proceso (Revista del Derecho Procesal, ano IX, vol. I, p. 136).

(75) Uma das características do processo oral e concentrado é a irrecorribilidade em separado das interlocutórias (cf. CHIOvENDA, Instituições, cit. vol. III, p. 81; idem, Saggi di Diritto Processuale Civile, Roma, 1931, vol. II, p. 32). Assim o sistema adotado por algumas legislações: da Alemanha, § 511; da Austria, § 462; da Hungria, § 479; de Basiléia, § 221; de Lucerna, § 443 . No mesmo sentidv, entre nós, Francisco Morato, A Oralidade (Rev. For. vol. 74, p. 145); Luís Machado GuImarães, o processo oral $e$ o processo escrito (Rev. For. vol. 74, p. 166). Parece-nos que, de tôdas as 1Lzuras de agravo que herdamos de Portugal, aquela cuja índole se adapta ao princípio da irrecorribilidade em separado das interlocutórias, é a do agravo no auto do processo. Coube ao eminente processualista MACHAdo Guimarães o mérito de haver sugerido a reviviscência dêsse recurso, por entender que êle se harmonizava com o processo oral e concentrado (Elíser Rosa, Do Agravo no auto do processo, in Rev For. vol. 124, p. 348). 
institutos diferentes; b) do ponto de vista sistemático, uma quantidade excessiva de meios de impugnar as decisões.

Ninguém duvida que a primeira condição do progresso jurídico é o rigor da linguagem; as palavras têm significação própria; não podem designar com um nome comum institutos diversos, nem institutos iguais com nomes diferentes. Todavia, o direito positivo nacional, sob o nome comum de agravo de petição, reune cinco recursos, cujas condições de admissibilidade são substancialmente diferentes. Ele é admissivel: I — da decisão que põe termo ao processo, sem entrar no julgamento do mérito (Cod. Proc. Civ. art. 846); II — da decisão terminativa da instância e da sentença proferida sôbre o pedido das partes (Dec. lei n. ${ }^{\circ} 960$ de 17 de novembro de 1938, art. 45); III — da decisão de mérito proferida nas ações de acidente do trabalho (Dec. lei n. 7.036 de 10 de novembro de 1944, art. 64); IV - nos casos expressamente indicados na lei de falências (Dec. lei n. ${ }^{\circ} 7.661$ de 21 de junho de 1945, arts. 18, $\$ 3 .^{\circ}$; $19 ; 69, \S 4 .^{\circ} ; 77, \S 4 .^{\circ} ; 79, \S 2 .^{\circ} ; 97 ; 137, \S 4 .^{\circ}$ e $155, \S 3 .^{\circ}$ ); V - da decisão do juiz, que nega ou concede mandado de segurança (Lei n. 1533 de 31 de dezembro de 1951, art. 12).

Pela simples indicação que acaba de ser feita bem se vê que o legislador brasileiro se serve indiferentemente de uma única expressão - agravo de petição - para designar recursos de decisões substancialmente diferentes. Admite o agravo de petição ora de decisão terminativa do processo, ora de sentença definitiva de mérito, ora de outros provimentos jurisdicionais de índole diversa. Não há, pois, um critério uniforme na sistemática dos recursos.

Essa diversidade de nomes tem sido também uma fonte de êrros, de enganos, de decepções. Qual o recurso admissível da sentença que decreta a prescrição? da que julga o autor carecedor dá ação? da que pronuncia a segunda e a terceira absolvição da instância? da que julga o concurso de credores? da que acolhe os embargos de terceiros? da 
que mantém o inventariante, tutor, curador, testamenteiro ou liquidante? da que decide sôbre a prestação de contas? Estas perguntas poderiam suceder-se em conta e sem resposta uniforme. Quinze anos depois de entrar em vigor o Código de Processo Civil, nem a jurisprudência, nem as opiniões dos doutores se tranquilizaram sôbre os recursos admissíveis nesses e noutros numerosos casos práticos. Por outro lado, tais recursos têm prazos diferentes para a interposição, a resposta e o preparo em primeira e segunda instância. Interpõe-se a apelação em quinze dias (76); os agravos, em cinco (77); de dez dias é o prazo para contra-arrazoar a apelação e de quarenta e oito horas para contraminutar o agravo (78). O prazo de preparo da apelação é de dez dias nos dois graus de jurisdição (79); e do agravo é de vinte e quatro horas em primeira instância e de cinco dias em segunda (80).

20. - Todos êstes males teriam sido evitados se o legislador brasileiro houvesse procurado, nos conselhos da experiência e no direito dos povos cultos, uma solução verdadeiramente cientifica para o sistema de recursos. Antes de mais nada, deveria ter fixado um critério, qualquer que êle fôsse, contanto que fôsse um critério. O legislador poderá reduzir a uma denominação única todos os recursos de decisões de primeira instância, chamando-os simplesmente apelação e determinando os casos em que ela é recebida em ambos os efeitos, ou só no efeito devolutivo e também quando o recurso pode ser processado seperadamente, nos próprios autos ou só conhecido por ocasião do julgamento da apelação principal. Outro critério se funda na natureza do provimento jurisdicional. $O$ recurso deve

(76) Cod. Proc. Civ. art. 823.

(77) Cod. Proc. Civ. art. 841.

(78) Cod. Proc. Civ. arts. 827 e 847.

(79) Cod. Proc. Civ. art. 832.

(80) Cod. Proc. Civ. art. 849. 
corresponder à índole da decisão. A apelação seria admissível das sentenças definitivas de mérito; os agravos, nos demais casos taxativamente indicados no Código, ou nas leis. Os prazos para interpôr e contra-arrazoar o recurso deveriam ser uniformizados para evitar tratamento desigual entre os litigantes. Em suma, o legislador brasileiro não adotou nenhum critério. Divorciado de qualquer preocupação científica ou sistemática, preferiu as soluções puramente empíricas.

21 - Outro defeito do Código é, a nosso ver, a quantidade excessiva de recursos. Queremos aludir especialmente a dois meios de impugnação de sentenças, nos tribunais de segundo grau, sem correspondente no direito comparado: os embargos de nulidade e infringentes $e$ a revista. Admite-se o primeiro quando não fôr unânime a decisão proferida em gráu de apelação. Se o desacôrdo fôr parcial, os embargos serão restritos à matéria objeto da divergência (81). Admite-se o segundo, nos casos em que divergirem, em suas decisões finais, duas ou mais câmaras, turmas ou grupos de câmaras, entre si, quanto ao modo de interpretar o direito em tese (82).

Qual a natureza jurídica dos embargos? Segundo o enunciado legal dêsse recurso, os embargos são de nulidade $e$ infringentes do julgado. O Código parece distinguir dois objetos: nulidade e infringência (83). Mas os embargos só são admissíveis quando o julgamento, proferido na apelação, é tomado por maioria, votando vencido um dos juízes. A divergência pode ser total ou parcial. Se o desacôrdo fôr parcial, os embargos serão restritos à matéria da divergência, não podendo versar sôbre a outra parte do

(81) Cod. Proc. Civ. art. 833.

(82) Cod. Proc. Civ. art. 853 (com a nova redação dada pela lei n. ${ }^{\circ} 1.661$ de 19 de agôsto de 1952).

(83) Cf. L. A. Costa Carvalio o Espírito do Código de Processo Civil, Rio, 1941, p. 271; João Claudino de Oliveira e Cruz, Dos recursos no Código de Processo Civil, Rio, 1954, p. 181. 
julgado em que a decisão foi tomada por unânimidade. Estabelecidos êstes princípios, cabe agora perguntar, que nulidades constituem objeto dos embargos? Quaisquer nulidades verificadas no decurso do processo, ou sòmente as ocorridas no julgamento da apelação? Ou, precisando melhor os têrmos, são os embargos restritos às nulidades acêrca das quais se manifestou a divergência no julgamento colegial?

Por outro lado, em que consiste a infringência? Cândido de Oliveira Filho ensina que "embargos ofensivos ou infringentes são aquêles que tendem a atacar a sentença em seus fundamentos, sem ser por matéria de nulidade, para que ela não subsista. Embargos modificativos da sentença são aquêles que, não tendo por fim destruí-la por nulidade, ou por qualquer outra causa, tendem a modificar-lhe os efeitos no todo ou em parte. "A infringência - dí-lo com precisão o desembargador Caetano Pinto de Miranda Montenegro - do verbo infringere - não observar, violar, transgredir a lei, preceito, pacto, etc. — os embargos, sob essa denominação, tendem, como os de nulidade, à reforma, ou revogação da sentença embargada, com fundamento na violação, ou inobservância da lei; os de nulidade, pròpriamente dita, em relação à sentença, em sua feição jurídica, contrariando a lei em sua tese ou preceito abstrato, si expressim sententia juris rigorem data sit; os infringentes, em relação à lei em hipótese, isto é, a interpretação judiciária da causa, determinando a situação jurídica dos litigantes" (84).

Pontes de Miranda elabora construção diversa: “Os embargos de nulidade e infringentes do julgado contêm dois recursos, - um, o que pode atacar assim a validade da sentença, como a validade do processo, se ainda não houve preclusão; outro, que afirma a injustiça do julgado.

(84) CÂndido de Oliveira FilHo, Teoria e Prática dos Embargos, p. 13 e seg. 
Ali trata-se de inadequada apreciação da validade do processo por parte da sentença inclusive quanto a ela mesma; aqui, de julgamento injusto do assunto, que é o seu objeto (res in iudicium deducta it iudicata); error quod processum e error quod rem também dito error in procedendo e error in iudicando. Ali, estão em causa pressupostos da sentença; aqui, o seu conteúdo." (85) Esta opinião adota um amplo conceito de infringência, pois abrange não só a ilegalidade, senão também a injustiça do julgado, apreciando a quaestio iuris e a quaestio facti. Ora, se o desacôrdo entre a maioria e o voto vencido é total e se a matéria se refere à injustiça do julgado, daí resulta que os embargos abrem umá nova instância (86) no segundo grau de jurisdição, à semelhança da apelação, permitindo rediscutir amplamente tôda a causa, nos mesmos têrmos em que foi devolvida ao Tribunal (arg. do Cód. Proc. Civ. art. 824); mas, ao contrário, se o recurso visa a atacar a nulidade ou a ilegalidade (ou ambos os vícios) do julgado, então a matéria aí se restringe só a pontos de direito, dando lugar a uma instância especial, não a uma terceira instância: qualquer que seja a interpretação, a verdade é que êsse recurso não parece ser necessário. Um recurso deve ser criado ou mantido na medida em que êle aperfeiçoe a decisão, sem retardar a administração da justiça. Os embargos pressupõem um julgado, proferido em grau de apelação por juízes, a quem não se pode negar notável saber jurídico, vasta experiência e reputação ilibada. A existência de um voto vencido não basta por si só para justificar

(85) Pontes de Miranda, Comentários ao Código de Processo Civil, vol. V, p. 160. Segundo Seábra Fagundes, Dos recursos ordinários em matéria civil, p. 378, infringência consiste "na injustiça na aplicação do direito substancial".

(86) João Mendes JR. Direito Judiciário brasileiro, p. 486, observa que "no Estado de S. Paulo, os embargos não são conhecidos e julgados sòmente pelos mesmos juízes do acórdão embargado, mas por todos os juízes do Tribunal. Êles tornam-se assim uma terceira instância.." 
a criação de tal recurso; porque, pela mesma razão, se devia admitir um segundo recurso de embargos tôda vez que houvesse mais de um voto vencido; desta forma poderia arrastar-se a verificação por largo tempo, vindo o ideal de justiça a ser sacrificado pelo desejo de aperfeiçoar a decisão.

22. - Não tem melhor fortuna o recurso de revista. Instituído com a finalidade de uniformizar a jurisprudência nos Estados - membros da Federação, foi, logo ao nascedouro, severamente criticado por eminentes juristas nacionais (87). O prof. Oscar da Cunha considera a revista "inutil, demorada, indigesta; é a mais ornamental homenagem que se pode tributar à chicana. Imprestável a mais não poder, atravancou o nosso mais alto tribunal local, roubando aos juízes e aos recorridos (vitimas dêsse absurdo, a que se deu honras de remédio judiciário), tempo, paciência e dinheiro; - multiplicou, sem proveito algum para a justiça os trabalhos forenses, mantendo em situação instável e intranquila centenas de soluções definidas com acêrto pela justiça ordinária." (88) O prof. Waldemar Ferreira se manifestou com igual veemência, na Câmara dos Deputados, por ocasião da discussão do projeto que se converteu na lei $n .^{\circ} 319$, dizendo que "o recurso de revista é uma excrescência, que carece ser abolida para sossêgo das partes e dos juízes" (89). Carvalho Santos proclama também a inutilidade da revista. "Em certo sentido", escreveu, "entendemos, mesmo, ser ali nocivo e prejudicial tal recurso, que passa a constituir um sério obstáculo a

(87) Há, porém, os que o aplaudem, ou pelo menos o justificam (SEABRa Fagundes, Dos Recursos Ordinários em matéria civil, p. 426; Pedro Batista Martins, Parecer, in Rev. Forense, vol. 90, p. 87$)$.

(88) OSCAR DA CuNHA, Breves considerações sôbre o Código do Processo Civil Brasileiro, Rio, 1935, p. 83 e seg.

(89) Cf. Mario Guimarães, Recurso de Revista, p. 5; Bilac Pinto e Lucio Bittencourt, Recurso de Revista, p. 10. 
que a jurisprudência venha a desempenhar a sua missão mais elevada, que é precisamente adaptar a lei às necessidades sociais." (90)

É verdade que a revista objetiva eliminar a divergência jurisprudencial na interpretação do direito em tese; e, sob êsse aspecto, pode ser considerada recurso extraordinário (91); mas, a nosso ver, a finalidade da revista, não se coaduna com o instituto da jurisdição, que é a função do Estado que tem por escôpo a atuação da vontade concreta da lei (92). Não é missão do poder judiciário dizer o direito em tese, ou in abstracto, mas sim compôr conflitos de interêsses, declarando e tornando efetiva a vonfade concreta da lei. O juiz não torna concreta na sentença a vontade da lei, que é abstrata; ao contrário, ela se concretiza no momento em que se dá a violação ou a ameaça ao direito subjetivo, ou quando gera um estado de incerteza objetiva. O juiz declara a vontade concreta da lei que preexiste à sentença.

Por outro lado, a revista eleva à categoria de motivo autônomo, ou fundamento do recurso a simples existência đo dissídio jurisprudencial (93). Ora, o que há aqui de censurável não é a interpretação divergente senão a vio-

(90) Carvalho Santos, Código de Processo Civil Interpretado, IX, p. 371.

(91) Pontes de Miranda, Comentários ao Código de Processo Civil, vol. V, p. 289.

(92) Chrovenda, Instituições de Direito Processual Civil, vol. II, n. ${ }^{\circ} 137$.

(93) Ocorre o mesmo com o recurso extraordinário fundado no artigo 101, III, letra "d" da Constituição Federal; mas Liebman (Instituições de Chiovenda, vol. III, p. 404, nota in-fine) considerou esse fundamento do recurso inconveniente e artificioso, "porque á decisão errônea e não a decisão divergente é que se deve fulminar. E uma divergência, mesmo flagrante, pode, com o andar Ło tempo, vir a justificar-se com a natural evolução das condições sociais."

Como observou Calamandei, o princípio da unidade do direito qleve ser entendido em relação ao espaço, não ao tempo; deve pro- 
lação ou falsa aplicação da norma jurídica; aquela podes inspirar-se em considerações superiores de adaptação do. direito às novas exigências sociais e constituir uma razão. de progresso; esta se reduz a. uma falsa interpretação da norma ou a sua errônea aplicação ao fato, o que compromete gravemente a dignidade do poder judiciário. Se no. seio do tribunal há divergência quanto à interprètação do direito em tese, é claro que as duas exegeses não devem subsistir simultâneamente, porque se uma delas é a verdadeira, a outra é necessàriamente a falsa. Mas para afas-. tar o vício da violação ou falsa aplicação da norma, confereo Código de Processo o recurso extraordinário, com fundamento no art. 101, III, letra "a" da Constituição Federal; a existência dêsse recurso, que visa a presservar a unidade do direito, desaconselha a criação de outro, preordenado. com funçã̃o autônoma, ou antes exclusiva, à eliminação de dissidio jurisprudencial (94).

curar-se a uniformidade da jurisprudência, isto é, uma uniformidade contemporânea, que não exclui uma diversidade sucessiva (La cassazione civile, vol. II, n. 31.)

(94) Esta mesma crítica vale para a instituto do prejulgado. O Código de Processo Civil dispõe no art. 861 que "a requerimento de qualquer de seus juízes, a Câmara ou turma julgadora poderá. promover o pronunciamento prévio das Câmaras reunidas sôbre interpretação de qualquer. norma jurídica, se reconhecer que sôbre ela ocorre ou pode ocorrer, divergência de interpretação entre câmaras ou turmas" A característica do prejulgado está no julgamento prévio sôbre o direito em tese, não sôbre direito em hipótese: suscitado pelọ juiz, não pela parte interessada. A função do prejulgado coincide com a da revista no ponto em que visam a eliminar divergência de interpretação de norma jurídica; mas distinguem-se: a) porque a revista é um recurso da parte; o prejulgado é requerido à câmara ou turma por um de seus juízes; b) a revista pres supõe uma divergência atual; o prejulgado, uma divergência eventual e futura; c) o prejulgado tem caráter preventivo e assenta interpretação que se deve adotar no julgamento do direito em hipótese; a revista visa, ao contrário, cassar a decisão recorrida que contravém interpretação diversa de direito em tese. 
23. - Resta apreciar, por último as decisões embargáveis no Supremo Tribunal Federal. A lei n. ${ }^{\circ} 623$ de 19 de fevereiro de 1949 mandou acrescentar ao art. 833 do Código de Processo Civil um parágrafo com a seguinte redação: "Além de outros casos admitidos em lei, são embargáveis, no Supremo Tribunal Federal, as decisões das Turmas, quando divirjam entre si, ou de decisão tomada pelo Tribunal Pleno." Êste é o parágrafo único do art. 833, que regula os embargos de nulidade e infringentes do julgado. Sob esta denominação, a lei criou um recurso, que visa a eliminar a divergência de decisões entre as turmas e entre estas e o Tribunal Pleno. A função dêsses embargos no Supremo Tribunal Federal corresponde à da revista na justiça local. Apenas mudam os nomes. A lei criou êsse recurso, porque o. Supremo se dividiu em turmas (95); e já agora, cindido, era natural que entre elas surgisse dissídio, agravado pela frequência com que os Ministros são substituídos por juízes, que decidem em maiorias meramente ocasionais. O fracionamento do Supremo em Câmaras ou turmas já era questão antiga e havia opiniões favoráveis e desfavoráveis a essa solução. A Constituição Federal de 1934 , art. 73 , § $2 .^{\circ}$ permitiu que a lei ordinária dividisse a Côrte Suprema em Câmaras ou Turmas: "Tam-

Tem-se discutido qual a natureza do prejulgado. Pontes DE Miranda (Comentários, vol. V, p. 321) considera-o "recurso de ofício" Gabriel de Rezende Filho (Curso de Direito Processual Civil, São Paulo, 1951, p. 161) nega-lhe o caráter de recurso e o define "medida administrativa".

(95) O decreto-lei n.o 6 de 16 de novembro de 1937 dispôs no art. 5 que "todos os feitos da competência do Supremo Tribunal Federal serão julgados por turmas de cinco juízes." $\mathrm{E}$ no $\S 2 .^{\circ}$ dêsse artigo preceituou: "O Supremo Tribunal Federal determinará quais os ministros que deverão compôr cada uma das turmas." . Na Sessão de 24 de novembro seguinte, o Supremo Tribunal, sendo relator da matéria o Ministro Costa Manso, aprovou a resolução, que distribuiu a competência do Tribunal pleno e de cada turma (Cf. Castro Nunes, Teoria e prática do poder judiciário, Rio, 1943, p. 186. 
bém, sob proposta da Côrte Suprema, poderá a lei dividí-la em câmaras ou turmas e distribuir entre estas ou aquelas os julgamentos dos feitos, com recurso ou não para o tribunal pleno, respeitado o que dispõe o art. 179."

Êsse dispositivo da Constituição de 1934 não foi reproduzido na de 1946, o que faz crer que não pode subsistir, sob o sistema constitucional vigente, a divisão do Supremo Tribunal em turmas. Assim pensa o Ministro Eduardo Espínola (96): "a Constituição de 1946 não autoriza expressamente a divisão do Supremo Tribunal Federal em turmas, diversamente do que dispõe em relação ao Tribunal Federal de Recursos (art. 103, \& único)." Ensina incisivamente Pontes de Miranda: "é de repelir-se a divisão do Supremo Tribunal Federal em câmaras ou turmas, para as matérias de competência do "tribunal" A divisão em câmaras, ou turmas, de modo a se distribuirem por aquelas ou essas os julgamentos dos feitos, podia ser com recurso ou sem recurso para o tribunal pleno. A respeito escreviamos e vale a pena ver que fomos ouvidos: "só os que não assistiram a trabalhos do antigo Supremo Tribunal Federal, os da antiga Côrte Suprema e os do Supremo Tribunal de hoje podem aplaudir a divisão em turmas. Reforma do Supremo Tribunal Federal que lhe restitua todo o prestigio de que desfrutava impõe-se a quem o considere, como nós o consideramos, o aparelho mais eficaz - quando compenetrado da missão de defender as liberdades individuais e a Constituição -- em República Federativa. Nunca se poderá deixar de exigir o tribunal pleno em se tratando de julgar da inconstitucionalidade de lei ou ato do Presidente da República (art. 96) e isso não quer dizer que a Constituição anui em que se extingam, em todos os outros casos, as funções do plenário do Supremo Tribunal. Se atendermos a que, além dos próprios Ministros do Supremo Tribunal Federal, os

(96) Eduardo Espínola, Constituição dos Estados Unidos do Brasil, vol. II, p. 451. 
Ministros de Estado, o Procurador Geral da República, os juizes dos Tribunais de Apelação, os Ministros do Tribunal de Contas e os Embaixadores e Ministros diplomáticos são julgados por êle, nos crimes comuns e de responsabilidade, - logo percebemos o perigo de se entregarem tais processos e julgamentos últimos a câmaras restritas e a turmas ocasionais". Vindos de ditadura e produtos dela, os juízes do Supremo Tribunal Federal, em "golpe de Estado" judiciário, sobrepuzeram à Constituição de 1946 o seu velho Regimento. As câmaras e turmas apareceram na Constituição de 1934, art. 73, $\S 2 .^{\circ}$, acima citado; a de 1946 de modo nenhum se referiu a elas" (97).

24 - Por outro lado, os trabalhos preparatórios da elaboração constitucional também desautorizam o fracionamento em turmas ou câmaras. $O$ anteprojeto da Constituição (art. 11) estava assim redigido: "o Supremo Tribunal Federal, com sede na Capital da República e jurisdição em todo o território nacional, compor-se-á de 11 Ministros. $\S 10^{\circ}$ - Esse número não será reduzido, mas poderá ser elevado por lei até 15 , precedendo proposta do Supremo Tribunal Federal. \& 2. ${ }^{\circ}$ - Também, por proposta do Supremo Tribunal Federal, poderá ser êste dividido em câmaras ou turmas, ressalvada a competência do Tribunal

(97) Pontes de Miranda, Comentários à Constituição de 1946, 1953; 2. ${ }^{a}$ ed., vol. III (arts. 98-140) pag. 9. Já se pensava assim antes da Constituição atual. Tal era a lição do Ministro CAstro Nunes: "Mas o Suprema Tribunal Federal é por sua natureza único, não comporta divisão em câmaras, porque a sua competência, tôda de base constitucional, supõe um corpo formado de onze ministros e são êsses onze, ou a maioria dêles, que hão de decidir os recursos extraordinários e, de lim modo geral, tôdas as questões que sobem ao seu conhecimento, originàriamente ou mediante recurso" (CAstro Nunes, A tarefa do Supremo Tribunal Federal, em Anais do Ministério de Justiça, n. ${ }^{\circ}$ 7, p. 2; idem, Teoria e Prática do Poder Judiciário, p. 184 e segs.; ver ainda Frladelfo de Azevedo, A Crise do Supremo Tribunal, nos cit. Anais n. ${ }^{\circ}$ I, p. 7 e segs.; Levi Carneiro, Ainda a crise do Supremo Tribunal Federal, em cit. Anais, n. ${ }^{\circ}$ II, p. I e segs.). 
pleno, nos casos previstos na Constituição e na lei" 0 § $2 .^{\circ}$, que autorizava a divisão em câmaras ou turmas, mediante proposta do Supremo, recebeu duas emendas: uma, do Prof. Ataliba Nogueira e outra, de Prado Kelly. Ambos propunham a supressão do parágrafo. As emendas foram aprovadas. Desapareceu o $\S 2 .^{\circ}$. O desembargador José Duarte, depois de fazer um histórico dos debates parlamentares na Assembléia Constituinte, concluiu: "vale considerar que, sôbre corresponder isso à relevância das questões afetas à apreciação da alta Côrte e mais bem condizer com a sua majestade, apresenta a vantagem de evitar que, muita vez, as divergências doutrinárias mantenham as turmas ou câmaras desavindas na fixação da jurisprudência. E para a justiça não há mal maior, nem desprestígio mais acentuado para o direito positivo, do que a flutação da jurisprudência e os desentendimentos dos julgadores sôbre a mesma tese ou a aplicação da mesma lei. A razão de ordem objetiva, material, ligada ao excesso ou acúmulo de trabalho jamais poderia sobrepor-se ao intrínseco interêsse da justiça e à própria solenidade e grandeza da Suprema Côrte" (98).

Apesar disso, o Supremo manteve a divisão em turmas. Êsse fracionamento deu ensanchas à formação de decisões divergentes, veiu ferir parcialmente a unidade do direito positivo nacional e propiciou a criação de mais um recurso, procrastinando o julgamento definitivo dos pleitos (99).

Chegamos ao têrmo desta conferência, Apresentamos o quadro do sistema de recursos e as sugestões para uma reforma de base. Estando no extremo confim do território

(98) José Duarte, A Constituição Brasileira de 1946, vol. II, pags. 229 e seg.

(99) Aos autores norte-americanos repugna a divisão da Côrte Suprema em turmas: WILloughBy, The Supreme Court, p. 108 e segs.; Bryce, La République Americaine, Paris, 1900, vol. I, p. 331; para o direito argentino, vejam-se as observações de Bielsa, Estudios de derecho publico, vol. III, p. 712 e segs. 
*a Pátria, nesta cidade que teve expoentes máximos de nossa história, onde vive e vibra uma plêiade de estudiosos da mais fina erudição e cultura, é aqui que se deve levanar a bandeira para a revisão do Código de Processo Civil. A inciativa dêsse trabalho, sério e consciente, confiado a homens de saber e de cultura, permitirá levar a cabo uma reforma que dignifique a consciência jurídica nacional, dotando o país de novo instrumento que facilite a obtenção de uma justiça rápida e eficaz. 